\title{
Fazer História: a importância de ler, interpretar e escrever em sala de aula, de Renilson Rosa Ribeiro Curitiba: Appris, 2018, 179ps.
}

Alessandro Mortaio Gregori Doutorando em Educaçâo do programa de Pós-Graduaçấo em Educaçáo da Faculdade de Educação da Universidade de São Paulo. São Paulo - SP - Brasil ORCID: https://orcid.org/0000-0001-6858-4100 amortaio@hotmail.com

O ensino de História retorna à pauta das discussões sobre o currículo escolar brasileiro. Nos últimos anos, durante a formulação da Base Nacional Curricular Comum (BNCC/2015-2018), a disciplina foi alvo de acalorados debates e, em seguida, tornou-se monitorada por um furacáo nomeado Escola Sem Partido. A história escolar vem ganhando destaque desde os anos de redemocratização do país, evidenciando sua competência de ser um espaço articulador de ideias e de exercício da cidadania. É nesse contexto que se deve compreender a obra do professor da Universidade Federal do Mato Grosso (UFMT), Renilson Rosa Ribeiro: Fazer História: a importância de ler, interpretar e escrever em sala de aula. A publicação do texto encontra um cenário pedagógico nacional em efervescência e ansioso por análises críticas sobre um presente que se vislumbra obscuro.

O autor investiga as práticas cotidianas dos professores de História a partir de uma determinada proposta: ler, interpretar e escrever como elementos essenciais do exercício rotineiro de alunos e professores. O objetivo é oferecer aos docentes da disciplina possibilidades de reflexão para o aprimoramento das práticas pedagógicas em sala de aula. Renilson afirma que a leitura e a escrita estendem-se ao longo de um amplo programa de alfabetizaçáo iniciado desde os primeiros anos de contato com a escola e prolongado durante toda a extensão da vida escolar. Ler e escrever náo se circunscrevem apenas às disciplinas de linguagem. Tais habilidades se fazem presentes no conjunto das componentes curriculares, cabendo a cada professor estipular suas ferramentas e estratégias para favorecer a alfabetização. Segundo o autor, o professor de história, ao promover atividades de leitura, interpretação e escrita colabora com a alfabetização o educando, uma vez que as práticas da língua são parte intrínseca da constituição dos saberes construídos em sala de aula (p.69-70). 
A obra se divide em três capítulos. O primeiro discorre sobre o lugar social da História como disciplina, assim como o papel da instituição escolar e dos professores na construção da consciência histórica dos alunos. O autor aponta a História como uma componente do currículo que tem passado, desde os anos 1980, por diversas revisôes, as quais sempre almejam trazer para a sala de aula modelos alternativos e novas formas de se trabalhar o conhecimento histórico, criticando intepretaçóes positivistas e esquemas globalizantes. No entanto, reconhece-se ainda a distância profissional entre o historiador e o professor de História. A erradicação desse divórcio mostra-se urgente. Segundo o autor, a separaçáo do pesquisador e do professor é resultado de impasses entre a implantação acelerada da escola de massas e a formação acadêmica do magistério que não favoreceram a criaçáo de uma estrutura de valorização do profissional de Educação Básica. Alijados dos debates oficiais, porém detentores de múltiplos saberes, os docentes ainda apresentam dificuldades em reconhecer sua profissão como exercício intelectual. Permanecem entre a categoria resquícios de uma concepção do ensino como mera técnica, enquanto, na visão do autor, deve-se considerar "a sala de aula como a oficina do profissional da História - pesquisador, educador e intelectual.” (p. 43)

O capítulo dois envereda pela a análise do contato cotidiano entre professores e alunos na construção do conhecimento histórico. Para Renilson, a aula tem a tarefa de romper com a ideia tradicional do saber como algo acabado, memorizado e reproduzido pelo aluno. $\mathrm{O}$ cotidiano de sala de aula deve ser interpretado como prática de pesquisa. Contudo, a pesquisa no universo escolar não pretende fazer do educando um historiador mirim, mas oferecer-lhe "uma formação crítica acerca de como compreender o mundo em que se vive.” (p.62) A formação crítica em Educação é reflexo de uma prática dialógica e libertadora, como já há tempos propôs Paulo Freire. Os atos de leitura, interpretação e escrita dáo sentido ao ensino-aprendizagem, revelando ao professor de História um processo de alfabetizaçáo prolongado, o qual não compreende leitura e escrita como meros pré-requisitos, mas sim como componentes fundamentais a ser aperfeiçoados a cada estágio escolar. Ancorado em pensadores como Michel de Certeau e Roger Chartier, Renilson atenta para o fato de que as práticas de leitura e escrita não podem ser encaradas pelos professores como abstração ou parte de um processo universal e a-histórico. Tais 
práticas não dão espaço para a imparcialidade ou neutralidade - o leitor é autor e o autor é leitor ao criarem mutuamente quadros de experiência e produzirem sentidos e interpretaçóes sobre os textos. Assim, as práticas de leitura e escrita advogam por um ensino sob a perspectiva da históriaproblema. Afastando-se da narrativa factual e homogeneizadora, as práticas de comunicação tradicionais da escola devem favorecer um ambiente de reflexão contínua, um livre espaço para a manifestação da consciência de professores e alunos.

O capítulo final, cerne da obra, pretende discutir estratégias e experiências vividas sobre o ensino de História, evidenciando a leitura e a escrita. Enquanto os capítulos anteriores aprofundaram a discussão sobre a disciplina História na escola em termos essencialmente teóricos, este terceiro tem como fonte de inspiraçáo as atividades desenvolvidas pelo autor nas salas de aula da Educação Básica. Renilson constrói o capítulo a partir de três elementos sobrepostos: currículo, materiais didáticos e experiências de práticas de ensino-aprendizagem. Porém, inicia a argumentação ressaltando a discussão sobre o que identifica como "diário das aulas", ou seja, a definição das escolhas do professor de História no momento em que planeja sua aula como uma oficina profissional. Para o autor:

O desafio [para o professor] está em saber definir o diário das aulas, diante das alternativas no próprio currículo da área, da abordagem do livro didático adotado pela escola, dos materiais e recursos didáticos existentes, da disponibilidade ou não do acervo da sala do professor e biblioteca e do perfil dos alunos. Em outras palavravas, as perguntas que precisam de resposta são: Para quem ensinar? O que ensinar? Como ensinar? (p.80)

A discussão prossegue com a análise das orientações curriculares, com foco nos Parâmetros Curriculares Nacionais (PCNs), documentos cuja versão final foi oficialmente apresentada pelo MEC em 1997. As proposiçóes dos PCNs, segundo o autor, apresentam referências para o trabalho das disciplinas escolares, ao mesmo tempo em que ressaltam a importância de se aproximar do currículo escolar uma série de temas transversais - Ética, Meio Ambiente, Orientação Sexual, Saúde, Trabalho, entre outros. Para Renilson, o referencial comum dos PCNs não se confi- 
gura como estrutura curricular homogeneizadora, mas sim uma chamada à pluralidade dos contextos e tradiçôes regionais. No campo da História, os PCNs assumem posiçóes advindas das tendências historiográficas brasileiras dos anos 1980, reconhecedoras da aproximação da História com as demais Ciências Humanas, assim como dos questionamentos sobre as fontes utilizadas para a construção do conhecimento histórico. Esses debates estão presentes nos PCNs e ajudaram a elaborar uma perspectiva sobre o ensino de História que está concentrada na identidade social do aluno e na elaboração de um saber histórico escolar que agregue consideraçôes das múltiplas representações sociais produzidas por alunos e professores.

Após estabelecer uma discussão contundente sobre os diários de aula e as escolhas dos professores sobre materiais de ensino, em especial o livro didático e sua articulaçáo com os documentos oficiais, o autor finaliza a obra com quatro sugestôes de atividades a ser realizadas nas aulas de História, propostas direcionadas aos alunos de Ensino Fundamental $\left(6^{\circ}\right.$ a $9^{\circ}$ ano). Renilson buscou nas atividades evidenciar os atos de leitura e escrita, dando ênfase às produçóes dos estudantes e a sua capacidade de ler, interpretar e produzir saber histórico. As propostas dialogam com os PCNs, incitando sua inclusão em eixos temáticos e temas transversais. Variam desde "os usos da água entre as sociedades do mundo antigo e América" (6ªno) à "Ditadura e formas de resistência no Brasil pela música." (9ªno)

Se o ensino de História tem reaparecido constantemente nos debates sobre currículo no país, isso revela o destaque da disciplina no rol de saberes considerados relevantes na constituição do sujeito reflexivo. A própria existência dos debates curriculares demonstra o caráter plural da componente curricular e seu compromisso de provocar inquietaçóes na busca por um espaço público democrático. A obra de Renilson exalta a importância de os professores se apropriarem do "fazer história", isto é, interpretar a sala de aula e os materiais produzidos para e nas aulas como objetos de pesquisa, com vistas à melhoria das práticas pedagógicas.

$\mathrm{O}$ distanciamento entre ensino e pesquisa tem produzido modelos pedagógicos que continuam a reproduzir saberes de pouca potencialidade reflexiva. No campo do saber histórico escolar, Renilson demostra que o lugar de fala dos professores é o "chão da escola". A busca por um ensino de história calcado na alfabetização histórica do educando não se limita às discussões técnicas sobre Educação ou exclusivamente nas epistemolo- 
gias da História que balizam a formação inicial docente; dizem respeito, também, à prática cotidiana, a qual enxerga a sala de aula como o "laboratório do professor". É a emersão da "aula como texto", nos dizeres de Ilmar Rohloff de Mattos e muito bem referenciado por Renilson (p.70). A aula será uma criaçáo sempre em curso, que renova permanentemente os objetos de ensino e transforma continuamente, não apenas o aluno, mas também o professor. 
